Article

\title{
Behavioral Facilitation of a Transition to Energy Efficient and Low-Carbon Residential Buildings
}

\author{
Robert A. Enker *(i) and Gregory M. Morrison $(1)$ \\ Curtin University Sustainability Policy Institute, School of Design and the Built Environment, Curtin University, \\ Perth 6102, Australia; greg.morrison@curtin.edu.au \\ * Correspondence: robert.enker@postgrad.curtin.edu.au
}

Received: 5 August 2019; Accepted: 18 October 2019; Published: 28 October 2019

\begin{abstract}
Reducing carbon emissions from the building sector is an international policy priority, as a consequence of the Paris Climate Accord obligations. The challenge for policy makers is to identify and deploy effective policy instruments targeting this sector. Examining the mechanics of policy operation in the residential sector is particularly instructive, because of the high level of building activity, diverse stakeholders, and complex policy considerations-involving both consumers and industry stakeholders. Energy policy initiatives undertaken by the European Union provide pertinent case studies; as does the operation of Australia's national building code. The paper builds upon earlier research examining the application of socio-economic transition theory to the regulation of the building sector. Here, building policy options are examined from a behavioral economics perspective, where stakeholder actions in response to strategic initiatives are considered in socio-psychological terms. The application of behavioral economics principles to building policy has the potential to impact all of the stages of the building lifecycle, from design through construction to operation. The analysis reveals how decision-making by building industry stakeholders diverges substantially from the assumptions of conventional economics. Significant implications then arise for the framing of building sector climate and energy policies, because behavioral economics has the potential to both contribute to the critical re-appraisal of current policies, and also to provide innovative options for refining interventions at key stages in the building lifecycle.
\end{abstract}

Keywords: buildings; behavioral economics; climate change; greenhouse abatement; policy instruments; regulation

\section{Introduction}

Following the ratification of the Paris Climate Accord in December 2015 [1] governments worldwide have been deliberating on the most effective means of delivering individual commitments to mitigate national greenhouse gas (GHG) emissions. A significant body of research suggests that the building/property sector provides an unequalled opportunity for GHG abatement [2-5] compared with other economic sectors.

The contribution of the IPCC (Intergovernmental Panel on Climate Change) Working Group Three to the IPCC Fifth Assessment Report provides a comprehensive overview of both the contribution of buildings to global GHG emissions, and the benefits and costs of mitigation for this sector [6]. Thus, the challenge facing governments is to devise the most effective, economically efficient policy instruments for intervention in the property sector, in order to exploit its GHG abatement potential.

When considering the formulation of policies designed to improve buildings' energy efficiency to reduce lifecycle GHG emissions, a typical approach is to view buildings as technical systems whose design is to be optimized in engineering and architectural terms [3]. This perspective point is given full expression in the application of socio-technical transition theory [7] to the building production 
process. An appreciation of transition theory can also be utilized in order to better understand the effectiveness (or otherwise) of building energy efficiency regulations [8].

By way of contrast, this paper approaches the question of building energy policy instruments through the perspective offered by behavioral economics (BE) theory in order to provide a fresh perspective to assist policy makers, thus complementing the earlier analysis of transition theory. BE has been defined as a method of economic analysis that applies psychology into human decision-making in the economic domain [9]. Note that in this paper, no distinction is drawn between BE and its sister discipline behavioral science [10].

BE seeks to re-assess conventional economic assumptions about individual perceptions and notions of value, and personal preferences. Thus, BE challenges the conventional concept of homo economicus, in which humans are seen as consistently rational agents who are driven by narrow self-interest [11]. Through psychological experimentation, BE has generated theories about human decision making and identified a range of biases in the way people think and feel [9]. Rather than making choices after careful deliberation, consumers often make intuitive judgements based on information that may be either readily accessible to memory, or prominent in the contemporary milieu, as explained by Kahneman [12]. In a practical sense, the modern school of BE owes its underpinnings to the work of Kahneman and Tversky [13]. Thaler has also played a key role in formulating BE theory and its practical application to public policy [11].

Synergies between BE theory and the domain of public policy have already been explored to some extent in the literature (for example in [14-16]). This analytical trajectory also extends the exploration of potential contributions from BE theory to the development of environmental policy [17], and more specifically to climate/energy policy $[18,19]$.

In regard to the application of BE principles to building energy performance and its supportive policy settings, the focus of academic reviews has tended to be on the facilitation of domestic energy conservation in a broad sense [20-22], rather than specifically on the intersection of stakeholder behavior with building design and operation per se. The objective of this paper is to address this gap in the academic literature by focusing on the application of BE to policy interventions that deal with building sector stakeholder behavior relating to decisions on building design, construction, and operation.

It is worth pointing out (even if notionally self-evident) the following:

- Building (energy) policy initiatives ultimately depend on their fulfillment and effective deployment on behavior change by property sector stakeholders;

- BE theory offers a rich body of evidence-based analysis that could be employed to enhance delivery mechanisms for these policy initiatives.

\section{Study Methodology}

The methodology for the research draws upon two complementary theoretical frameworks to examine the policy role of building energy regulations. These twin theoretical frameworks are socio-technical transition theory and behavioral economics. This paper is directed to examining potential synergies between behavioral economics and building energy policy. The methodology employed in the research project parallels the approach taken by Elbaz and Zait [23] in their investigation into the use of behavioral tools to mitigate domestic consumers' electricity consumption. This approach is based on combining a systematic literature review with detailed reference to secondary sources, then undertaking the consequent analysis and synthesis.

The paper opens by articulating the directly congruent relationship between global climate policy and building sector greenhouse gas (GHG) mitigation measures on the basis of information provided by a systematic literature review of the field. The next stage of the analysis is to review policy options-that is, alternative instruments—-for the deployment of building energy policy that has developed as a consequence. 
Next, the conceptual base and relevance of BE is discussed through of a review of the pertinent literature, in order to demonstrate how BE can be relevant to building policy formulation and implementation. This examination also indicates where gaps currently exist in the relevant research literature.

Case studies of building policy implementation are examined below (Section 5), as a vehicle for developing the analysis. This section of the paper also includes a critique of the current regulatory, economic, and informational approaches to building energy policy.

The paper concludes with a discussion on the analytical findings, leading to proposals for applying BE principles to building energy policy.

The paper aims to map out a fresh policy landscape arising out of an application of BE theory to the building sector. Recommendations are made for further studies to progress this evolving area of academic inquiry, together with proposals for the application of lessons from BE theory specifically to the residential property market.

\section{Linking Climate Policy with Building Energy Policy}

The concept of a policy trajectory that runs directly from global responses to climate change (enshrined in the 2015 Paris Climate Accord) [1] through measures to prioritize sectoral energy efficiency in national economies is particularly helpful in taking this analysis forward. This conceptual trajectory can then be extended to measures that specifically target the building sector for government intervention. By adopting this perspective, the role of building energy policy in meeting global climate change objectives is brought to the fore and is highlighted.

Moreover, this strategic hierarchy clearly indicates that a deliberate policy focus on building energy efficiency and low-carbon buildings is vital if national climate change policies are to be effective. A pertinent report by the International Energy Agency [24] confirms that judiciously implemented building energy codes have a key role to play in the deployment of national building energy policies. By drawing on the principles of socio-technical transition theory, it can also be shown that building codes have a substantial transformative impact on the customary behaviors and practices at play in the building industry [8].

A variety of analyses have been concerned with the various policy instruments available to governments seeking to mitigate GHG emissions from the building sector. A study conducted for the United Nations Environment Program (UNEP) by the Central European University provides a concise overview of such policy options [25]. Other studies have also sought to address energy efficiency options from a broader perspective, which addresses an aggregate policy mix rather than individual policy instruments [26].

For the purposes of this paper, the classification and categorization of policy instruments has been developed from a structure proposed by Rosenow [26], which is in turn based on article seven of the EU Energy Efficiency Directive [27].

A high-level review of the literature suggests that these policy instruments may be grouped into the following three broad categories for practical purposes, so as to facilitate further strategic analysis $[26,28,29]$ :

1. Economic and financial interventions;

2. Regulatory approaches, including codes and standards;

3. Information provision, consumer engagement, and industry capacity building.

Therefore, the comprehensive EU classification has been divided into three principal categories suggested by the literature (Table 1). This classification is also broadly consistent with a structure proposed by the International Energy Agency (IEA) [29].

In an analysis directed at understanding policy principles related to the greening of household behavior generally, rather than simply driving energy efficiency, the Organization for Economic 
Cooperation and Development (OECD) takes a similar approach to the categorization of policy instruments [30], identifying these as the following:

- Taxes, charges, and subsidies

- Direct regulation

- Information provision

- Provision of infrastructure (by governments).

Table 1. Categorization of building energy policy instruments.

\begin{tabular}{cc}
\hline EU Classification [29] & Analytical Classification \\
\hline Carbon taxes & Economic/financial \\
Finance schemes and fiscal incentives (grants and loans) & Economic/financial \\
Tax rebates & Economic/financial \\
Regulations or voluntary agreements & Regulatory \\
Energy labeling schemes & Informational \\
Standards and norms & Regulatory \\
Training and education programs & Informational \\
\hline
\end{tabular}

By way of comparison, United States policy-makers at both national and state government levels have deployed a whole range of policy measures defined by this classification system [31].

\section{Foundations of Behavioral Economics}

\subsection{Understanding Human Behaviour}

BE seeks to challenge the way that classical economics deals with people's perceptions of value, choices, and preferences. BE suggests that the conventional model of homo economicus [11] is open to being challenged, in that people are not necessarily self-interested, benefit maximizing and cost minimizing individuals with stable preferences. In Kahneman's terms [13], a similar distinction is drawn between the rational econs who operate in the realm of classical economic theory, and the ostensibly irrational humans who inhabit the domain of BE.

Personal choices are often not made after careful deliberation [13], but can be rather impetuous, subject to the decision-making context, and supported by information that readily comes to mind. Kahneman makes the distinction between the intuitive, rapid, relatively effortless System 1 decision-making processes, and measured, deliberate System 2 thinking processes.

It is in the expedient System 1 area that the employment of heuristics by property market participants plays such an important role. A heuristic is defined as a mental shortcut or unconscious mental rule of thumb used by individuals to simplify decisions by substituting an easier question for a more difficult one [9,32]. Studies in the BE field suggest that people are actually conservative, resistant to change, risk averse, subject to distorted memory, and not particularly skilled in allocating economic cost and benefits to future events [11]. So, as consumers of goods and services in the free market, $\mathrm{BE}$ theory proposes that we are in effect predictably irrational [33]. This observation mirrors the conclusion reached by Blasch et al in a study on consumer responses to the display of appliance energy efficiency [34] -individuals with a higher level of investment literacy are more likely to undertake an exercise in economic optimization, rather than relying on a decision-making heuristic; such individuals are also more likely to identify and purchase cost-efficient appliances in the first instance.

The concepts derived from BE theory have significant implications for the development and implementation of government policy in areas as diverse as public finance, health management, and consumer protection. In fact, the potential policy repercussions of BE have given rise to an increasingly multidisciplinary approach to this discipline; that is, taking it beyond a narrow economic perspective [10], as also evidenced by the rise of the parallel discipline of behavioral science [10]. 
To date, BE has been applied to various areas of government policy, such as consumer protection, finance, labor market reform, energy policy education, and health services [35]. Recent evidence suggests that the previously limited application of BE principles to the built environment may now be changing [36]. Governments seeking to capitalize on the contribution that BE principles can make to enhanced policy delivery typically approach this task through the establishment of dedicated behavioral insight teams (BITs).

Major studies done recently by the World Bank [15] and the OECD [35] have catalogued these initiatives on a global scale. These studies have found that specialized public sector organizational units have been set up as arms of the central government in countries such as the United Kingdom, the United States, Australia, Canada, Denmark, France, Germany, Singapore, Peru, and the Netherlands in order test the application of BE principles to government policy development processes. Significantly, the World Bank and OECD reviews also found that projects being undertaken by BITs tended to be further experimental and investigatory in character; which reflects the relative immaturity of $\mathrm{BE}$ utilization as a policy instrument in global terms.

In the particular domain of energy policy that is the focus of this paper, the application of BE theory has been limited to areas such as the provision of consumption data to consumers, promoting the uptake of renewable energy, improving the transparency of energy contracts, and the roll-out of smart metering systems [35].

\subsection{BE Principles: The Crucial Central Role of Heuristics}

A recurrent and central theme of BE theory has been the development of a deeper understanding of the impacts of heuristics on consumer behavior [13]. According to BE theory, heuristics are mental shortcuts used to cope with difficult, rationally taxing questions by substituting simpler and more intuitive answers [10]. The overwhelming array of decisions facing a consumer buying a new home [37] provides a prime example of when heuristics typically come into play.

The approach taken in this paper to investigating the application of $\mathrm{BE}$ principles, to the modification of the behavior of stakeholders in the building sector is illustrated in Figure 1. Selected heuristics are used as a surrogate for BE theory in operation, then the impact of these heuristics is mapped against projected behaviors of building sector stakeholders during the course of market operation. The results of this mapping exercise are set out in Table 2.

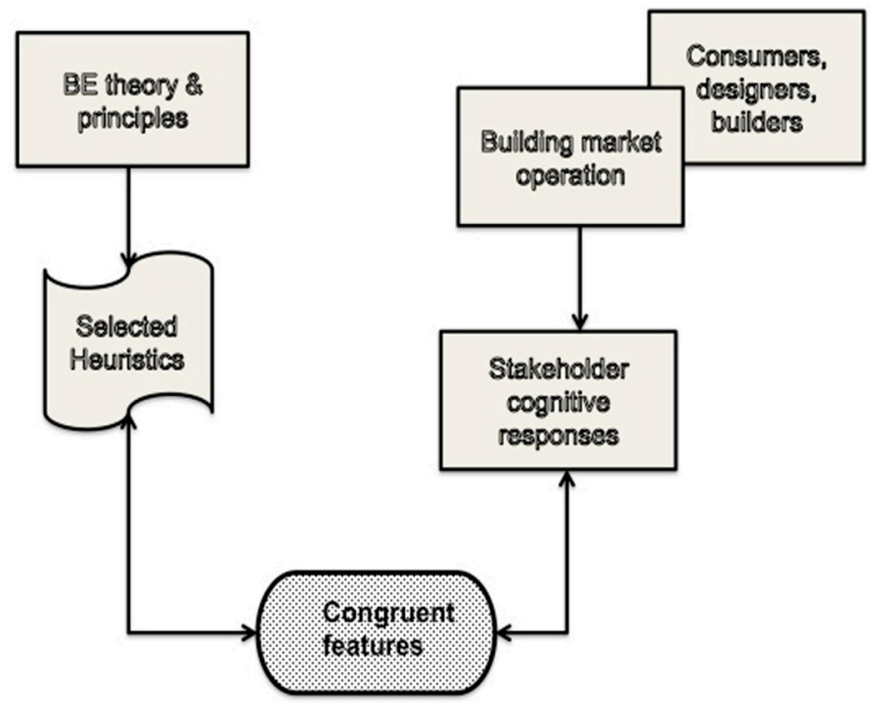

Figure 1. Approach to examining the impacts of behavioral heuristics on the cognitive processes employed by the building sector stakeholders, and the potential congruence between these features. 
Table 2 sets out a selection of heuristics distilled from the much wider group that have been developed within the BE discipline. This subset has been chosen because of its relevance to the operation of the market for building products and services; it is deliberately intended to provide the reader with an initial grasp of the relevance of cognitive heuristics to consumer behavior and decision-making in relation to the goods and services available in the property market.

Table 2. Heuristics developed under BE theory: applicability to property market operation.

\begin{tabular}{|c|c|c|}
\hline Heuristic & Description & Property Market Example \\
\hline Anchoring & $\begin{array}{l}\text { Initial exposure to a value serves as a } \\
\text { reference point for subsequent } \\
\text { decisions and choices }\end{array}$ & $\begin{array}{l}\text { Setting pricing points for new } \\
\text { consumer goods and capital } \\
\text { investments, such as new homes }\end{array}$ \\
\hline Availability & $\begin{array}{l}\text { People make judgments about the } \\
\text { likelihood of an event based on how } \\
\text { easily an example comes to mind }\end{array}$ & $\begin{array}{l}\text { Consumers rely on anecdotal advice } \\
\text { from friends, family, and other } \\
\text { non-expert sources for investment } \\
\text { decisions }\end{array}$ \\
\hline Bounded rationality & $\begin{array}{l}\text { Bounded rationality challenges } \\
\text { attributes of homo economicus; } \\
\text { limited thinking capacity creates } \\
\text { bounds [11] }\end{array}$ & $\begin{array}{l}\text { Self-limited decision making by } \\
\text { residential building purchasers (see } \\
\text { also choice overload) }\end{array}$ \\
\hline Choice overload & $\begin{array}{l}\text { This phenomenon is a consequence of } \\
\text { the excessive choices available } \\
\text { to consumers }\end{array}$ & $\begin{array}{l}\text { Excessive decisions facing home } \\
\text { buyers for building features, } \\
\text { appliances, and fit-out [38] }\end{array}$ \\
\hline Cognitive bias & $\begin{array}{l}\text { Systematic thinking errors and } \\
\text { deviation from desirable and } \\
\text { accepted norms }\end{array}$ & $\begin{array}{l}\text { Also termed keeping up with the } \\
\text { neighbors for major } \\
\text { consumer purchases }\end{array}$ \\
\hline Confirmation bias & $\begin{array}{l}\text { People seek out or evaluate } \\
\text { information in a way that fits with } \\
\text { prior beliefs }\end{array}$ & $\begin{array}{l}\text { Industry stakeholders are change } \\
\text { averse, preferring traditional choices } \\
\text { (also known as herd behavior) }\end{array}$ \\
\hline Framing effect & $\begin{array}{l}\text { Choices expressed to highlight } \\
\text { positive (or negative) aspects of a } \\
\text { decision, leading to changes in } \\
\text { relative attractiveness }\end{array}$ & $\begin{array}{l}\text { The marketing of consumer goods is } \\
\text { carefully managed so as to promote } \\
\text { positive features and gloss } \\
\text { over negatives }\end{array}$ \\
\hline Herd behaviour & $\begin{array}{l}\text { People emulate others' decisions and } \\
\text { do not make independent decisions; } \\
\text { the collective irrationality of financial } \\
\text { investors creates stock market bubbles }\end{array}$ & $\begin{array}{l}\text { Conformity in product design and } \\
\text { selection becomes a fashion } \\
\text { statement, rather than objective } \\
\text { decision-making }\end{array}$ \\
\hline Present bias & $\begin{array}{l}\text { People give stronger weight to payoffs } \\
\text { closer to the present time; distant } \\
\text { rewards have a relatively low } \\
\text { perceived value }\end{array}$ & $\begin{array}{l}\text { Investment in energy efficiency is } \\
\text { simplistically based on upfront } \\
\text { rather than lifecycle costs }\end{array}$ \\
\hline Social norm & $\begin{array}{l}\text { Signal appropriate behavior according } \\
\text { to social group norms or expectations; } \\
\text { social norms may differ from market } \\
\text { exchange norms }\end{array}$ & $\begin{array}{l}\text { Keeping up with the neighbors is an } \\
\text { expression of such behavior; links to } \\
\text { herd behavior and cognitive bias }\end{array}$ \\
\hline Status quo bias & $\begin{array}{l}\text { Preference for stasis through inaction } \\
\text { or adherence to prior decisions; occurs } \\
\text { for low transition costs but } \\
\text { high-decision importance }\end{array}$ & $\begin{array}{l}\text { Owners can be reluctant to upgrade } \\
\text { poorly performing assets despite } \\
\text { compelling economic evidence }\end{array}$ \\
\hline
\end{tabular}

It is evident from Table 2 that numerous "fast thinking" [12] cognitive heuristics are utilized by individuals confronted with important and complex decisions, such as those facing homebuyers or renovators. The pervasive influence of these heuristics lends weight to analyses suggesting 
that consumer behavior diverges significantly from the "rational actor" model favored by orthodox economics in relation to market operation in the property sector, for example [11,39].

\section{Options for Market Intervention by Policy Makers}

While in theory, governments have a range of policy instruments at their disposal (Table 1) for mitigating GHG emissions from residential buildings, all of these interventions ultimately have one critical feature in common, namely: they are all directed towards triggering behavior change by building sector participants. Thus, the effectiveness of these market interventions must be measured by the degree of behavior change achieved. Later case studies in the paper (Sections 5.1-5.3) explore this question in detail.

A review of the literature suggests that a number of studies have been undertaken to identify and ideally optimize the mix of market interventions deployed by policy makers. For example, Rosenow [26] reiterates the observation that energy efficiency measures are expected to play a key role for meeting European Union targets to reduce energy use and GHG emissions. Rosenow [26] developed a framework for assessing combinations of building energy policy interventions that, it is suggested, will be more effective than the single policy measures that are typically subjected to scrutiny.

Lorch [40] observes that the success of policy interventions to reduce GHG emissions from building stock have been met with limited success for a number of reasons, including —of particular relevance to this analysis-failure to address the social aspects of building design and operation, with an over-emphasis on technical solutions. It is in this area of the social dimensions of building policy that $\mathrm{BE}$ theory has a potentially powerful role to play.

In a report specifically addressing the Australian building policy setting, Harrington [41] suggests that the key elements of an optimal carbon and energy policy framework for the built environment should include, inter alia, the following: national emissions targets, effective carbon pricing, strong emphasis on compliance with energy performance regulations, encouraging over-compliance with the minimum building code requirements, and encouraging an enhanced carbon performance for existing building stock. It is in these latter three areas in particular that BE tools have a potentially powerful role to play.

\subsection{Policy Lessons from BE Theory}

The analysis now moves on to consider how BE theory might be utilized to offer insight into the behavior of designers and residential builders responding to the requirements of performance-based building codes.

Regulations seek to change the behavior of architects and building designers. Financial measures aim to elicit a rational behavioral response from property developers, owners, and investors. Information campaigns typically aim to modify consumer choice and decision-making practices. Therefore, BE can provide powerful insights into the effectiveness of such policy instruments. BE can help determine whether desired behavioral modifications are actually being achieved in practice, and if not, which changes to policy settings are called for as a remedy.

A summary of the key actors operating in the property market is set out in Table 3. Reference to the headline heuristics set out in Table 2 provides explanations as to why industry stakeholders may behave in an irrational manner [33], rather than conforming with or responding rationally to the opportunities for innovation and creativity offered by performance-based building codes. Table 3 further develops the basic BE heuristics set out (Table 2) earlier, by identifying their applicability to specific stakeholder groups active in the building sector/property market. 
Table 3. Heuristics operating in the building sector defined in terms of affected stakeholder groups amenable to interventions based on BE principles.

\begin{tabular}{|c|c|c|}
\hline & Sectoral Manifestation & Influenced Stakeholder Groups \\
\hline Anchoring & $\begin{array}{l}\text { Designers set energy performance } \\
\text { levels at a regulatory minimum, } \\
\text { thereby failing to explore } \\
\text { alternatives with increased } \\
\text { consumer benefits }\end{array}$ & $\begin{array}{l}\text { Building designers and architects } \\
{[42,43]}\end{array}$ \\
\hline Availability & $\begin{array}{l}\text { Consumer choices influenced by } \\
\text { well-marketed project home } \\
\text { designs that may lack innovation, } \\
\text { together with informal word of } \\
\text { mouth information }\end{array}$ & $\begin{array}{l}\text { Consumers (also meaning } \\
\text { homebuyers) [44] }\end{array}$ \\
\hline Bounded rationality & $\begin{array}{l}\text { Homebuyers face complex choices } \\
\text { and multi-faceted decisions, and } \\
\text { energy efficiency is a low priority } \\
\text { in this context }\end{array}$ & $\begin{array}{l}\text { Consumers and industry } \\
\text { professionals }[34,45,46]\end{array}$ \\
\hline Choice overload (decision fatigue) & $\begin{array}{l}\text { Complexity of decisions facing } \\
\text { consumers seems overwhelming, } \\
\text { leading to status quo defaults }\end{array}$ & $\begin{array}{l}\text { Consumers and service providers } \\
{[15,37,38]}\end{array}$ \\
\hline Social norm & $\begin{array}{l}\text { The McMansion syndrome } \\
\text { emphasizes cosmetic building } \\
\text { features over performance } \\
\text { characteristics, using comparison } \\
\text { with neighbors as an indicator of } \\
\text { social or material success }\end{array}$ & $\begin{array}{l}\text { Developers, consumers, and } \\
\text { builders }[18,19,47]\end{array}$ \\
\hline Status quo bias & $\begin{array}{l}\text { Owners of existing buildings resist } \\
\text { investment in building upgrades }\end{array}$ & $\begin{array}{l}\text { Investors, consumers, and } \\
\text { homeowners }[43,46,47]\end{array}$ \\
\hline Temporal discounting & $\begin{array}{l}\text { Payback benefits of investments in } \\
\text { energy efficiency widely } \\
\text { overlooked or ignored, with } \\
\text { buyers focused largely on upfront } \\
\text { capital costs rather than lifetime } \\
\text { operating costs }\end{array}$ & $\begin{array}{l}\text { Developers, investors, consumers, } \\
\text { and builders }[18,21,46,48]\end{array}$ \\
\hline Confirmation bias & $\begin{array}{l}\text { Energy efficiency features } \\
\text { discounted to consumers as } \\
\text { excessively expensive by building } \\
\text { practitioners on the basis of } \\
\text { pre-conceived notions of value }\end{array}$ & $\begin{array}{l}\text { Developers, consumers, builders, } \\
\text { and service providers [49] }\end{array}$ \\
\hline Framing effect & $\begin{array}{l}\text { Product information is focused on } \\
\text { superficial, tangible aesthetic } \\
\text { elements rather than subtle factors, } \\
\text { such as the benefits of } \\
\text { high-performance dwellings }\end{array}$ & Developers and consumers [47-50] \\
\hline
\end{tabular}

Notes: (1) McMansion syndrome describes a consumer preference for purchasing excessively large houses, specifically in the new project home market segment. Citations provided in the table refer to articles dealing specifically with issues of energy policy, rather than property market operation more generally.

Moving on from this analytical step, one is then in a position to identify opportunities for targeted market interventions that are directed towards achieving defined energy policy objectives for the building sector. Linking synergistic aspects of BE theory with the operational objectives of building energy policy will enable the identification of opportunities to improve existing policy instruments. The operation of the heuristics set out in Table 3 in the building sector has evident implications for policy formulation and delivery, which warrant further study. 


\subsection{Building Codes, Regulations \& Standards}

The effectiveness of building regulations and appliance standards as policy instruments for reducing GHG emissions in both developed and developing economies has been demonstrated extensively in the literature available from academic [25] and industry sources [3]. Major international organizations have also examined the issue, reaching similar conclusions concerning the usefulness of building performance standards (codes) as a preferred instrument for government interventions, which aim to give effect to international commitments for GHG emission abatement $[28,29,51]$. The effectiveness of building codes as a vehicle for reducing GHG emissions through the promotion of energy-efficient design practices has also been demonstrated in a number of ex-post studies (such as [52-55].

Furthermore, there is a consensus that best practice building regulations should be performance-based rather than prescriptive in character [56,57]. Performance-based building codes have now been adopted in jurisdictions as diverse as Australia, Austria, Canada, China, Japan, the Netherlands, New Zealand, Norway, Singapore, Sweden, Spain, the United Kingdom, and the United States [58]. While these performance-based regulations focus specifically on energy efficiency outcomes rather than buildings' elemental features, their effective implementation is crucially dependent on a rational response to the mandated performance requirements by designers, architects, and engineers [59]. Gann [60] suggests that the benefits of flexible performance-based regulations are quite wide-ranging, providing firms with market incentive and institutional frameworks within which to innovate.

\section{Case Study: Australia's Building Code}

Australia's National Construction Code (NCC) has, from its inception in 1996, been structured as a performance-based building regulation [61]. Evidence obtained from ex-post studies of the NCC in operation [55] demonstrates that the effective implementation of mandatory performance-based building energy standards can deliver significant consumer benefits, in that the compliance costs can be reduced as a consequence of the industry learning processes [62] that effectively contribute to market transformation [8].

As building codes such as Australia's NCC are amended at regular intervals [63], such step changes offer an opportunity to analyze the operation of the socio-technical transition processes that these reforms trigger [8]. At this point, building designers have a choice between either re-specifying by making incremental changes to existing designs; or comprehensively re-designing their projects in order to take full advantage of the code performance requirements. The latter response is intrinsically rational, while the former is irrational, and exemplifies Kahneman's System 1 thinking in practice, when viewed from a BE perspective [12].

A study of the industry learning processes at work in the Australian building sector [62] suggests that industry sectors respond differently to the upgrading of building energy standards, as follows:

- The commercial sector-responsible for major developments comprising a relatively small proportion of aggregate market activity—has a positive response to energy-efficiency requirements, frequently exceeding the minimum compliance levels

- The residential volume builder sector-responsible for around half of new home building — design response typically includes a combination of design changes and re-specification, with the minimization of incremental cost as a key criterion

- Small residential builders-responsible for around 50\% of local home building-typically respond with re-specification, an expensive compliance pathway for consumers. This conclusion is consistent with the degree of cultural conservatism and change aversion evident in this sector [64].

Research undertaken for the building regulatory agency in the State of Victoria, Australia, following the introduction of more stringent residential energy efficiency standards in 2006, sheds further light on the behavior of industry stakeholders [65]. An improvement, of some $25 \%$ in thermal efficiency, 
was observed during the implementation period for the new building energy standard. However, this improvement was shown predominantly as being attributable to increased building insulation levels (re-specification), rather than to more integrated design solutions that actually took advantage of the performance-based residential energy efficiency standard (redesign) [65]. A recent thorough analysis of the code-compliant home energy ratings by Moore [66] demonstrates that as-designed performance tends to cluster tightly around the stipulated regulatory minimum levels, rather than taking advantage of performance-based code objectives for truly optimum performance, from a consumer perspective. In effect, this situation represents a substantive market failure [56].

Another important constraint on the effectiveness of building codes in practice is substantive compliance with mandated energy performance requirements; as has been pointed out in the studies from the United Kingdom [57]. The Australian situation is possibly even worse than that of the United Kingdom, according to a recent review of compliance with NCC energy efficiency provisions conducted for the Government of South Australia [67]. This forensic study of code compliance concluded that the prevailing industry attitude was generally characterized by a disturbing combination of ignorance and apathy in relation to energy-efficiency provisions. Full compliance with energy performance requirements was the exception to the norm, consumer awareness of the energy efficiency objectives was low, and the prevailing attitude of industry stakeholders was that under-performance in the energy domain was unlikely to be detected or sanctioned by regulators (or homebuyers either). Thus, one can see that the potential effectiveness of building codes as an instrument of energy policy is likely to be compromised, unless their implementation is carefully managed, utilizing a perspective that draws on behavioral principles grounded in an appreciation of industry culture.

Returning to the property sector heuristics set out Table 3 illustrates how a BE perspective can provide insight into the effectiveness of regulatory interventions through a deeper understanding of the particular heuristics that are applicable to this regulatory case study, namely:

- Anchoring [42,43]

- Cognitive bias [48]

- Bounded rationality [34,43-45]

- Confirmation bias [49]

- $\quad$ Temporal discounting $[18,21,45]$.

\subsection{Financial Instruments Utilized for Energy and Climate Policy Operation}

A summary of the available financial instruments is provided in the discussion paper prepared for the IEA [31], which sets these out as the following:

- Direct taxation of $\mathrm{CO}_{2}$ emissions

- Emissions trading schemes (ETS)

- Taxes on process inputs or outputs (fuel or vehicle taxes)

- Subsidies for emission reductions.

In order to examine the potential congruence between BE theory and building energy policies, the case of ETS application will be investigated in some detail, because ETS represents a particularly significant and widely adopted element of national climate change policy in both developed and developing nations.

Case Study: ETS and Residential Buildings

A study for the UK Government [68] made the case for an ETS, asserting that setting a carbon price must be an essential foundation for climate-change policy. Another key public policy document in debates around climate change mitigation is the Fifth Report of the IPCC [69]. The IPCC confirms Stern's position [68], that carbon-pricing mechanisms including cap-and-trade schemes or carbon taxes 
have the potential to achieve cost-effective mitigation, provided that such schemes are supported by good policy design and governance regimes.

By making emitters such as companies and consumers bear the full environmental costs of their actions, they would be influenced to switch away from high-carbon goods and services, and invest in low-carbon alternatives. Such price signals operate by increasing the relative cost of carbon-intensive, energy-inefficient buildings, so stakeholders are encouraged to shift their focus to lower carbon alternatives. This crucial behavioral change in the decisions and market choices being made by businesses and consumers is the fundamental, inescapable objective of carbon-pricing policies. However, this objective is equally often overlooked in public policy debates.

Drawing on the analysis set out in Table 3, it can be seen that a BE perspective offers insight into the effectiveness of price-based market interventions through a deeper understanding of the behavioral heuristics that are applicable here, namely:

- $\quad$ Bounded rationality [34,43-45]

- Social norm (herd behaviour) $[18,19,47]$

- Temporal discounting $[18,21,45]$.

The impact of these behavioral heuristics on the property market is to cause irrational behavior by consumers, which tends to undermine the financially rational responses to higher energy prices on which carbon-pricing market interventions are based [42].

This important observation implies that additional instruments may need to be deployed by governments in support of carbon pricing, if desired policy outcomes are to be achieved in the residential building sector $[70,71]$.

\subsection{Stakeholder Information Provision}

According to an IEA analysis [31], policy initiatives that may be classified as information and voluntary approaches include the following:

- Public information campaigns

- Education and training, including industry capacity building

- Product certification and labeling

- Award programs.

Within this category, governments in many national and regional jurisdictions have placed considerable emphasis on policy instruments that utilize the performance rating and labeling of buildings as a vehicle for market intervention, with the aim of reducing GHG emissions from buildings. The rationale behind this intervention pathway assumes that performance disclosure will lead to changes in consumer behavior as a consequence of such information provision. Thus, it is assumed that consumers will respond by purchasing or renting buildings with superior performance ratings.

An extensive analysis on the benefits of energy performance certification (EPC) schemes for buildings, as well as best practice implementation processes, has been undertaken by the IEA [72]. EPC also offers additional benefits, such as increased public energy awareness, lower consumer costs, and improved building data collection, as an input to further policy development.

$\mathrm{BE}$ heuristics that potentially influence the operation of climate change and energy efficiency information provision policies include the following:

- $\quad$ Bounded rationality [34,43-45]

- Choice overload (decision fatigue) $[15,37,38]$

- Temporal discounting $[18,21,45]$

- $\quad$ Social norm (herd behavior) $[18,19,47]$. 


\subsubsection{Case Study: European Union Building Certification Program}

The European Union's Energy Performance of Buildings Directive (EPBD) [73] represents a major policy intervention in the building sector, which aims to deliver significant improvements in the energy efficiency of building stocks in all building sectors, for both new and existing buildings. The sweeping ambitions of the EPB program are encapsulated in its stated objective of delivering nearly zero energy buildings (NZEB) post 2020.

EPC is a key element of the EPBD. This EPC program is intended to be an instrument for market transformation by providing an information tool for market actors, such as building owners and occupiers; creating demand for building energy efficiency; influencing real-estate transactions; and offering recommendations for performance upgrades $[66,74]$. Because EPC is concerned with triggering behavior change in industry stakeholders through the provision of information, its operation can be examined through the lens of BE theory when evaluating program effectiveness.

High-level analyses of EU EPC program efficacy, such as Arcipowska [66] tend to focus on process control and quality assurance issues (certifier accreditation, centralized data collection, and legislative governance) rather than actual program outcomes measured against core policy objectives. However, Arcipowska [66] does recognize the need for an independent analysis of EPC program effectiveness. With this in mind, EPC reviews undertaken at a national level are illuminating.

In a study of ten national EPC programs, Backhaus et al. [75] found the impact of EPC's on home purchasing decisions to be low. Analyzing the Norwegian housing market, Olaussen [76] found no evidence that the labels have a substantive market impact or result in a price premium for superior certified performance. In a study of the Dutch residential property market, Murphy [77] concludes that the potential impact of EPC in driving efficiency improvement in existing buildings is problematic, unless complementary policy instruments are deployed to address multiple [78] barriers. In a Swedish study, Harsman [79] suggested that consumers are influenced more by information obtained from site visits than by EPC disclosure information; hence EPCs are not likely to stimulate market decisions in favor of energy efficiency or conservation. The German housing market has been investigated by Amecke [70], in order to assess the influence of EPCs on owner-occupied dwelling purchasers' decisions to incorporate energy efficiency into their purchasing decisions. This study concluded that energy certification actually had a limited influence on consumers.

Perhaps the most telling observation on the policy impact of current EPC programs in the EU comes from an extensive in-depth study by Backhaus, of 3000 homeowners in ten EU jurisdictions [71]. This analysis was based on a combination of in-depth interviews and a large-scale survey, which established that the EPC has a negligible impact on home-owner decision-making. These findings [71] have been attributed to a number of factors, namely: poor EPC availability, lack of awareness, and lack of understanding. These findings point to substantial flaws in consumers' behavioral responses to EPC disclosure information, in comparison to policy assumptions underlying the EPC program.

To sum up, the inadequacies in a key EU building policy initiative are attributed to unexpectedly weak and irrational consumer responses to EPC certificates. This outcome is one that a review of EPC through the lens of BE might well have anticipated (Table 3). Further consideration of the potential synergies between BE (heuristics) and the effective delivery of building energy policy measure is provided later in the paper (for example, Table 4).

\subsubsection{Choice Overload: A Daunting Challenge Facing Homebuyers and Renovators}

Purchasing or renovating the family home is a major strategic and financial decision that is undertaken relatively infrequently; hence, consumers do not have substantive personal experience to draw upon [37].

A general analysis of the negative effects of the excessive choice options available in modern consumer societies is also applicable to the housing purchase decision scenario. Schwarz [38] demonstrates how excessive consumer choice, rather than being beneficial, can frequently lead to unhappiness; disappointment; and, ultimately, even mental depression $[33,38]$. 
An experimental investigation by Malhotra [37] into how information overload affects consumer decision making for house purchasing found the following:

- The decision to buy a house normally entails substantial information seeking and processing;

- A house is a product that is used and understood by almost everybody;

- It is a complex product that is evaluated in terms of many salient attributes.

Two pertinent conclusions are set out in Malhotra's study, namely:

- Consumers struggle to make detailed comparisons of more than ten alternative choices, without experiencing cognitive dysfunctionality;

- Under decision overload conditions, consumers fail to make detailed comparisons of all alternatives, but adopt simplifying strategies (heuristics) to cope with the task of ranking options.

Another useful study examines the consumer choice dilemma in the case of purchasing a prefabricated house [80]. This study identifies no less than thirty parameters that must be taken into account by prospective homebuyers at a strategic decision-making level. When taken in conjunction with Malhotra's finding, that decision stress takes effect where choice alternatives reach ten or more [37], this result suggests that prospective home purchasers operate under a cognitive regime of considerable stress and significant dysfunctionality. So, consumers need active support to successfully navigate the daunting and complicated residential property market.

This area of consumer behavior is influenced by a number of the cognitive heuristics and biases articulated previously under BE theory (per Table 3), namely:

- $\quad$ Bounded rationality [34,43-45]

- Choice overload $[15,37,38]$

- Cognitive bias [48]

- Confirmation bias [49]

- Framing effect [47-50]

- Temporal discounting $[18,21,46,48]$

- Social norm (herd behaviour) $[18,19,47]$.

\subsection{Quantification of the Benefits of Residential Sector Intervention}

It was explained in the Introduction that this article of necessity takes a qualitative approach to an examination of the contribution that BE might make to building energy policy and its subordinate regulatory instruments. Nevertheless, one can provide pertinent quantitative examples of the impact of effective policy implementation based on information available from the literature. Here, the example of Australian National Construction Code will be utilized in order to illustrate the potential effectiveness of BE-based enhancements to building energy codes.

An overview of the economic benefits of progressive reforms to Australian residential building energy standards over a decade, based on data publicly available from national regulatory impact assessment reports [9], suggests that the regulations have a benefit-cost ratio of up to 4.6:1, and deliver carbon abatement at a negative cost (cost saving) of AUD $\$ 70 /$ tonne- $\mathrm{CO}_{2}$.

Further evidence for the benefits of building energy codes, this time in the United States context, is provided by Livingston [54], who determined that the net present value of cumulative energy and cost savings from the United States codes over the study period of 1992-2040 was $\$ 230$ billion. It is worth noting that -in the context of this article's central theme concerning the application of BE to improve the effectiveness of energy policy instruments-that Livingston makes a considered attempt to allow for non-compliance with building code provisions, to the extent of $25-30 \%$, in estimating the economic benefits arising from US code implementation [54].

A recent report prepared for the Australian Sustainable Built Environment Council (ASBEC) [81] provides quantitative evidence on the energy consumption of high performance, energy efficient 
buildings in comparison with a conservative base case. ASBEC finds that base case energy consumption for a code-compliant apartment building in the Melbourne, Australia, climate zone would be $73 \mathrm{kwh} / \mathrm{m}^{2}$; adopting an accelerated reform trajectory for the building code would bring forward a revised energy efficiency target of $57 \mathrm{kwh} / \mathrm{m}^{2}$, corresponding to savings of some $\$ 300 /$ year on the energy bill. By the same token, ASBEC reports that a base case annual energy consumption of $45.6 \mathrm{kwh} / \mathrm{m}^{2}$ could be reduced to $30.5 \mathrm{kwh} / \mathrm{m}^{2}$ through the accelerated deployment of more ambitious energy efficiency standards in the National Construction Code.

\section{Discussion}

It is unarguable that an effective response to the challenge of climate change and its contributory GHG emissions must include an explicit policy focus on the building sector [2-5,54]. To this end, a coherent response by governments calls for the deployment of diverse, complementary policy instruments $[26,82,83]$.

The effective implementation of building energy policy ultimately depends on achieving an intended behavioral change by the respondent sectoral stakeholder group. These outcomes require engagement with property developers, contractors, lessees, builders, or individual consumers, depending on the market sector targeted by the policy measure in question. For example, in the residential sector, consumers and building service providers are seen to be the key target stakeholder groups.

This paper seeks to break new ground by examining residential building energy policy interventions using a BE approach, wherein the behavior of key stakeholders such as consumers, designers, and builders, is addressed from a socio-psychological perspective. Although BE theory is being applied to policy implementation in areas such as consumer protection, finance, and public health, its principles have yet to be applied to the key building sector in the core area of building performance (as energy efficiency). It is worth reflecting on the contribution of residential building performance, including services such as water heating, to total residential energy demand. According to a definitive study by the Australian Government [75], residential space conditioning and water heating accounts for over $60 \%$ of the total residential energy consumption, with the balance taken up by electrical appliances and cooking. So, policy interventions focused on improved building design and construction are particularly important for reducing residential energy consumption, as downstream interventions directed towards reducing demand during building operation will inevitably be constrained by structural factors.

Working from a grounding in BE theory, the paper explains how decisions made by building industry stakeholders differ substantially from those assumed by an orthodox (essentially economic) policy perspective. This divergence has significant implications for the framing of sectoral climate and energy policies. Thus, BE theory suggests that understanding and applying inferences drawn from an appreciation of the cognitive heuristics at play among stakeholders can contribute to a marked improvement in the prospects for successful policy intervention, to deliver sustained behavioral change. Conversely, failure to heed the lessons available from BE theory is likely to jeopardize prospects for successful policy deployment.

A high level of complementarity between key elements of BE theory-represented by cognitive heuristics-and the behavioral triggers that building energy policy seeks to influence (Table 2) has been demonstrated. So, it follows that lessons available from BE theory might make a substantial contribution to the development of the government policy instruments that are being deployed to accelerate the transition to an energy efficient, low-carbon residential building stock (see Table 4 below for examples).

In a series of case studies (Section 5), the operation of each major category of building energy policy intervention was examined in turn. This section of the paper clarifies and reinforces the strong relationship between the tenets of BE theory and the mechanics of building policy. More revealingly, each category of policy implementation is shown to suffer from significant flaws-deficiencies that 
might reasonably be attributed, at least prima facie, to a failure by policy makers to appreciate the implications of the behavioral changes expected from targeted stakeholder groups. The utilization of $\mathrm{BE}$ principles through the application of appropriate heuristics offers a powerful vehicle for addressing these identified policy shortcomings.

Reviewing these policy failures through a BE lens better explains the following:

- Why compliance with energy efficiency requirements mandated in building regulations may be fatally compromised as a result of indifference by both building project developers and consumers;

- Why price-based interventions in the property market (such as through an ETS) will not necessarily prompt a rational response from consumers;

- Why consumer information campaigns such as the EU EPC initiative fail to achieve a significant market impact, or a price premium for superior certified performance, because of weak and irrational consumer responses.

These findings are summarized in Table 4, together with selected references from the literature that could provide a platform for the development of more effective market interventions based on BE principles.

BE theory suggests that understanding and applying inferences to be drawn from an appreciation of the cognitive heuristics at play among industry stakeholders could contribute to a marked improvement in the success of policy interventions, delivering a sustained behavioral change. But failure to heed the lessons available from BE theory is likely to jeopardize prospects for successful building policy deployment.

Despite the strong case for a focus on energy efficient buildings in terms of a global climate response, this policy area has yet to be appreciated by government BITs. A recent OECD study [35] into the potential application of BE principles to energy policy development concluded that areas for exploring the application of behavioral insights should specifically focus on regulatory implementation and decision making by regulatory agencies.

In the domain of climate and energy policy, which is the focus of this paper, the application of $\mathrm{BE}$ theory has tended to address aspects of consumer engagement with energy markets, such as the provision of consumption data, energy contract provisions, smart metering systems, and barriers to the uptake of renewable energy. Although the planning, design, construction, and operation of building projects could reasonably be seen as the essential focus for building policy, these aspects have yet to addressed by behavioral insight teams and other governmental proponents of BE.

As explained earlier, although BE has the potential to inform all stages of public policy development, its application by governments, to date, has been quite variable [14]. Many governments around the world have established BITs whose role is to explore the use of BE in public policy, and advise government agencies on the value of $\mathrm{BE}$ and behavioral science. However, the worldwide application of BE to public policy is still limited-most efforts are seen as operating in the exploratory or pilot phases [14]. Numerous case studies do demonstrate the successful application of BE theory to public policy in areas such as consumer protection, education, energy, environment, health and safety, taxation, telecommunications, public service delivery, and labor market reform [35].

Expanding the methodology for this study takes the discussion on to Figure 2. Here, the relationships between the final stages of the analysis are re-examined in order to demonstrate how further research into the enhancement of building policy instruments using BE theory might now be developed as a consequence. 
Table 4. Application of BE measures to correct shortcomings in market interventions, as demonstrated in preceding case studies.

\begin{tabular}{|c|c|c|c|c|}
\hline Building Energy Policy Measure & Intended Success Measures & $\begin{array}{l}\text { Substantive Outcomes (See Case } \\
\text { Studies) }\end{array}$ & $\begin{array}{l}\text { Behavioral Insights: Consideration of } \\
\text { Applicable Heuristics and Corrective } \\
\text { Interventions }\end{array}$ & Pertinent References \\
\hline $\begin{array}{l}\text { Carbon pricing-emissions trading } \\
\text { schemes }\end{array}$ & $\begin{array}{l}\text { Reductions in domestic energy } \\
\text { consumption; market preference } \\
\text { and higher valuation for low carbon, } \\
\text { energy efficient buildings }\end{array}$ & $\begin{array}{l}\text { Limited success in operation; } \\
\text { ineffective in the property } \\
\text { market [39] }\end{array}$ & $\begin{array}{l}\text { Influence of social norms_-try nudging } \\
\text { Status quo bias correction needed } \\
\text { Bounded rationality impedes policy } \\
\text { delivery }\end{array}$ & $\begin{array}{l}\text { Allcott } 2010 \text { [18]; Allcott } 2011 \text { [20]; } \\
\text { Allcott } 2014 \text { [47]; Fredericks 2015 } \\
\text { [21]; } \\
\text { Baddeley } 2011 \text { [45]; Baddeley } 2016 \\
\text { [46]; Blasch } 2017 \text { [34]; Lunn } 2014 \\
\text { [15]; Yoeli } 2017 \text { [50] }\end{array}$ \\
\hline $\begin{array}{l}\text { Regulation through building energy } \\
\text { codes }\end{array}$ & $\begin{array}{l}\text { Code compliance; aspirational } \\
\text { design objectives beyond code } \\
\text { minima (performance-based } \\
\text { code design) }\end{array}$ & $\begin{array}{l}\text { Widespread non-compliance }[57,67] \text {; } \\
\text { performance levels cluster tightly } \\
\text { around code set point } \\
\text { minima }[56,65]\end{array}$ & $\begin{array}{l}\text { Anchoring around regulatory minimum } \\
\text { performance standards } \\
\text { Use social norms with performance } \\
\text { transparency to encourage compliance } \\
\text { Loss aversion influential if coupled with } \\
\text { improved regulatory enforcement }\end{array}$ & $\begin{array}{l}\text { Klotz } 2010 \text { [42]; Klotz } 2011 \text { [48]; } \\
\text { Fredericks } 2015 \text { [21]; Moore et al. } \\
2019 \text { [57] }\end{array}$ \\
\hline Energy performance certification & $\begin{array}{l}\text { Market preference for higher rated } \\
\text { buildings-reflected in their } \\
\text { market value }\end{array}$ & $\begin{array}{l}\text { Consumer indifference gives rise to } \\
\text { ongoing market failure: energy } \\
\text { efficiency gap persists }\end{array}$ & $\begin{array}{l}\text { Anchoring, availability, and } \\
\text { choice overload } \\
\text { Bounded rationality and choice } \\
\text { overload may be addressed through } \\
\text { timely nudges } \\
\text { Unhelpful framing needs correction: } \\
\text { disclosure of operating costs not ratings } \\
\text { Temporal discounting is a } \\
\text { major impediment }\end{array}$ & $\begin{array}{l}\text { Baddeley } 2016 \text { [46]; Baddeley } 2011 \\
\text { [45]; McNamara } 2011 \text { [44]; Lunn } \\
2014 \text { [15]; Yoeli } 2017 \text { [50]; Blasch } \\
2017 \text { [34]; Shealy } 2016 \text { [51]; Allcott } \\
2010 \text { [18]; Fredericks 2015 [21] }\end{array}$ \\
\hline
\end{tabular}




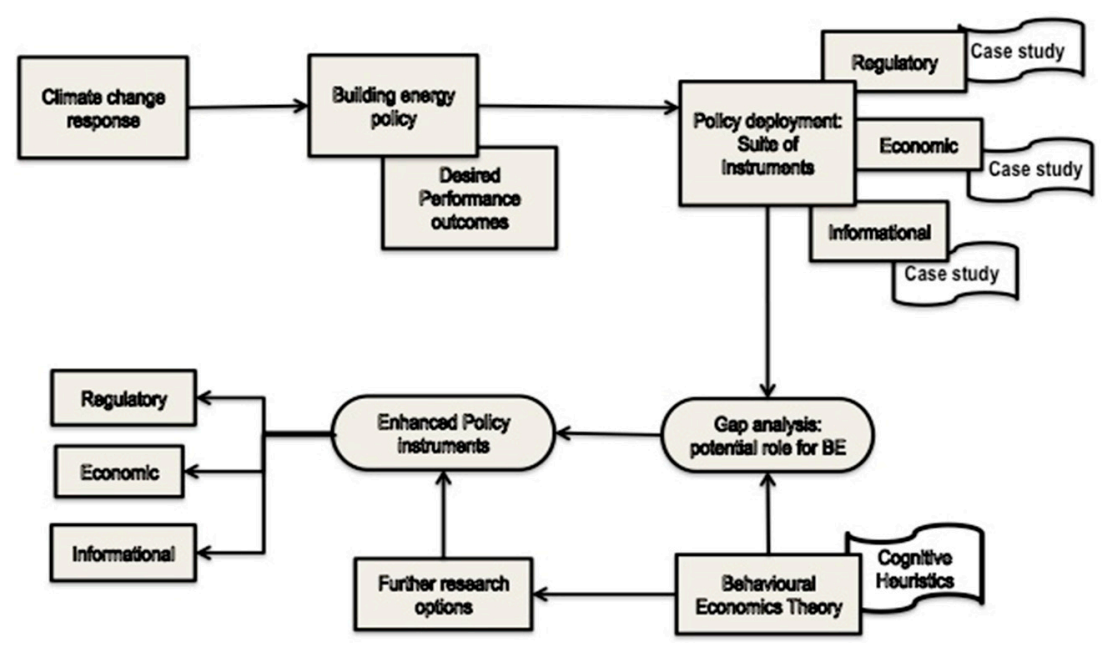

Figure 2. Overview of the key analytical elements at a concluding stage, illustrating the methodological process followed in the analysis; beginning from a review of policy settings, through to the discussion of policy deployment instructions, on to a gap analysis of the potential role for BE in building policy that then leads to findings on the enhancement of policy instruments.

\section{Conclusions}

This study has not attempted to provide an exhaustive review of BE theory or the principles of climate response policy. Its scope is limited to highlighting potential areas of alignment between BE theory and those energy policy interventions that are focused, in particular, on the residential building sector. This approach facilitates the identification of opportunities for drawing on BE principles to enhance the effective operation of building energy policy instruments; that is to say, regulations, financial interventions, and information provision programs.

The study's headline conclusions may be summarized as follows:

- Strong complementarity exists between the key tenets of BE-as represented by cognitive heuristics - and the mechanics of building energy policy

- Understanding the impact of cognitive heuristics on industry stakeholders' behavior can provide important contributions to the improved design of market intervention policies

- Policy implementation vehicles such as building energy codes, carbon pricing, and consumer information campaigns suffer from significant delivery failures, whose underlying causes could be better diagnosed and corrected through the application of BE principles (via heuristics)

- The economic and environmental argument for market intervention using building energy codes rests on assumptions of operational effectiveness, and high levels of regulatory compliance; without compliance, such projected benefits are illusory

- Behavioral insights not only hold out a promise of improved effectiveness for building policy delivery, but also the threat of compromised program outcomes, should the BE lessons fail to be learned

- Governments worldwide are calling on BE theory to improve the effectiveness of policy delivery in diverse areas such as consumer protection, education, public service delivery, and labor market reform; these nascent initiatives are typically managed by specialized BITs

- Application of BE theory to (building energy) policy by government BITs has tended to focus on consumer engagement with energy markets; the equally important issue of building project delivery, from conception through, design and construction, to operation, has yet to be well examined from a BE perspective

- Clearly, the next step for governments is to broaden the remit of their BITs in order to address building energy policy from a rigorous and broad-based BE perspective. 


\section{Further Research}

One outcome of this analysis is that further research is shown to be valuable, if the contribution of $\mathrm{BE}$ to building energy/climate policy is to be successfully exploited, as follows:

- Understanding the drivers and influencers of consumer choice and rationality-the role and true potency of building performance disclosure

- Facilitating and accelerating industry learning processes to entrench effective change management, particularly in the residential building sector

- Identifying international best practice approaches to building regulation in the context of behavioral factors and influences

- Understanding industry culture and the operation of peak industry bodies, as these relate to policy support and delivery

By way of a concrete example, a number of suggestions for the practical application of BE principles to the residential property market can be deduced from the analysis (see Table 4).

First, is to recourse to BE nudging techniques to persuade building industry professionals into committing to the delivery of high performing buildings that actually exceed code minima and aim at achieving zero carbon performance levels. A nudge is defined as a non-regulatory intervention that alters the choice architecture without effecting economic incentives [9,84]. In the same vein, one could envisage the use of targeted heuristics to engage consumers in a collaborative journey directed towards the delivery of low carbon homes with performance levels comparable with the Passivhaus standard, for example [85].

A second approach might be to address widely recognized building code compliance and enforcement problems $[56,57,64,65,67]$ by employing lessons from BE to properly understand, and then redirect, the response of industry stakeholders to meeting regulatory obligations. Here, the heuristics of social norms and loss aversion are likely to be applicable.

A third proposal might be to provide consumers with representative blueprints of good design to simplify decision-making and address the problem of choice overload (Table 2). This approach mirrors the strategies being developed by BITs in a number of jurisdictions to simplify financial decision-making, by providing consumers with default choices. The State Government of Victoria, Australia, recently introduced a relevant initiative. Recognizing that complex and poor-value electricity supply contracts were disadvantaging consumers, the State Government decided introduce a simplified, government mandated default power supply offering. This initiative also links directly to the issue of choice overload; it is expected to save individual electricity customers up to $\$ 2000 /$ year.

Interestingly, the design blueprint approach was implemented in the State of Victoria over sixty years ago. With the support of one of the country's leading architects and a local newspaper, the Small Home Service, it offered local homebuyers an inexpensive package of architect plans, working drawings, and construction specifications. Recently, Australia's national government has made archetypal designs for sustainable, energy efficient homes available freely to the public through a national communications program known as Your Home [86].

It is noteworthy here that Kruzner's analysis draws attention specifically to the need for policy interventions to deliver the consumer benefits flowing from passive solar residential designs [87].

In a study on the influence of cost-reflective electricity pricing, Hobman [22] sought to apply BE principles to the identification of opportunities for enhancing customer response by a cross-section of the population. This paper offers transferable insights that could also be applied to the investigation of linkages between BE, and building energy policy and regulation. Hobman [22] examined a series of salient heuristics (mirroring those presented in Table 3) in order to demonstrate how these behavioral biases act as barriers to the responses to cost-reflective pricing by consumers that were intended by policy makers. Similar behavioral barriers exist in the case of the effective operation of building energy standards; a comprehensive review undertaken for the Australian government clearly demonstrates shortcomings of precisely this type [67]. 
Finally, it is worth reflecting on the fact that the residential property market is a prime opportunity for the application of BE principles to building energy policy. This is the case, because the residential property purchase and ownership lifecycle includes a series of key decision points that provide potential intervention opportunities to facilitate behavior change, using tools such as nudging $[9,49]$.

These potential nudge points (highlighted on Figure 3) represent opportunities to alter the architecture of consumer choice at key decision points, by employing non-regulatory BE techniques that do not effect underlying project economics. It is at these points in the building lifecycle that heuristics come into play for industry stakeholders. Therefore, it is also these points that provide optimal intervention opportunities for policy makers making use of BE instruments, such as nudges. This strategy is illustrated in Figure 3, which mirrors findings by Yoeli [49], that interventions directed at modifying consumer choice architecture are most effective if focused on transition points in building lifecycle decision-making by consumers.

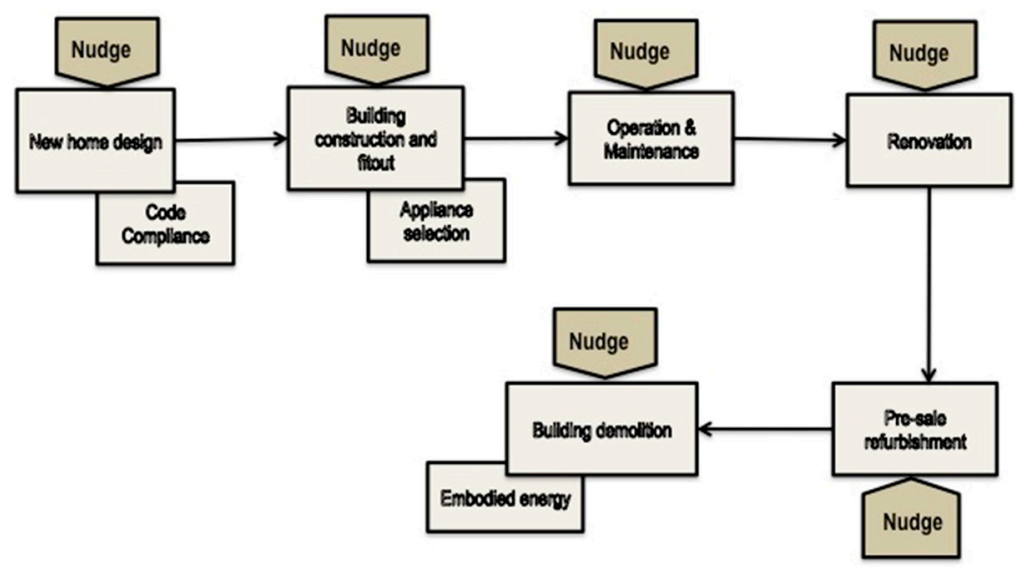

Figure 3. Key decision points in the residual building ownership lifecycle that present opportunities for the application of BE change management tools, such as nudging, in order to more effectively achieve desired policy outcomes.

Author Contributions: conceptualization, R.A.E.; methodology, R.A.E. and G.M.M.; investigation, R.A.E.; resources, R.A.E.; writing—original draft preparation, R.A.E.; writing-review and editing, R.A.E. and G.M.M.; visualization, R.A.E.; supervision, G.M.M.; project administration, R.A.E.; funding acquisition, R.A.E.

Funding: This research was funded by the Cooperative Research Centre for Low Carbon Living, Sydney, Australia, under Research Project RP1021.

Conflicts of Interest: The authors declare no conflict of interest. The funders had no role in the design of the study; in the collection, analyses, or interpretation of data; in the writing of the manuscript, or in the decision to publish the results.

\section{References}

1. United Nations. Paris Agreement; United Nations: New York, NY, USA, 2016; Available online: https: //treaties.un.org (accessed on 24 October 2019).

2. McKinsey Company. Pathways to a Low Carbon Economy: Version 2 of the Global Greenhouse Gas Abatement Cost Curve; Mckinsey Company: Washington, DC, USA, 2009.

3. World Business Council for Sustainable Development. Energy Efficiency in Buildings: Transforming the Market; WBCSD: Geneva, Switzerland, 2009.

4. Edenhofer, O.R.; Pichs-Madruga, Y.; Sokona, E.; Farahani, S.; Kadner, K.; Seyboth, A.; Adler, I.; Baum, S.; Brunner, P.; Eickemeier, B.; et al. (Eds.) IPCC, 2014: Summary for policymakers; Cambridge University Press: Cambridge, UK; New York, NY, USA, 2014.

5. Australian Sustainable Built Environment Council. Low carbon, high performance; Australian Sustainable Built Environment Council: Sydney, Australia, 2016; p. 136. 
6. Luzon, O.D.Ü.-V.; Ahmed, A.Z.; Akbari, H.; Bertoldi, P.; Cabeza, L.F.; Eyre, N.; Gadgil, A.; Harvey, L.D.D.; Jiang, Y.; Liphoto, E.; et al. Buildings. In Climate Change 2014: Mitigation of Climate Change. Contribution of Working Group. III to the Fifth Assessment Report of the Intergovernmental Panel on Climate Change; Centre for Environmental Policy, Imperial College: London, UK, 2014.

7. Geels, F.W.; Schot, J. Typology of sociotechnical transition pathways. Res. Policy 2007, 36, 399-417. [CrossRef]

8. Enker, R.A.; Morrison, G.M. Analysis of the transition effects of building codes and regulations on the emergence of a low carbon residential building sector. Energy Build. 2017, 156, 40-50. [CrossRef]

9. Samson, A. The Behavioural Economics Guide 2018 (Introduction by Robert Cialdini). 2018. Available online: https://BehavioralEconomics.com (accessed on 30 May 2019).

10. Behavioral Science and Policy Organization. Behavioral Science and Policy Website. Available online: https://behavioralpolicy.org/about/ (accessed on 26 January 2018).

11. Thaler, R. Misbehaving: The Making of Behavioural Economics, 2nd ed.; W.W. Norton.: New York, NY, USA, 2016; p. 415.

12. Kahneman, D. Thinking, Fast and Slow/by Daniel Kahneman; Allen Lane: London, UK, 2011.

13. Kahneman, D.; Slovic, P.; Tversky, A. Judgment under Uncertainty:Heuristics and Biases; Cambridge University Press: Cambridge, UK, 1982.

14. Afif, Z.I.; William, W.; Calvo-Gonzalez, O.; Dalton, A.G. Behavioral Science around the World: Profiles of 10 Countries (English); World Bank: Washington, DC, USA, 2019.

15. Lunn, P.A. Regulatory Policy and Behavioural Economics; OECD: Paris, France, 2014.

16. Leigh, A. How behavioural economics does and can shape public policy. Econ. Labour Relat. Rev. 2015, 26, 339-346. [CrossRef]

17. Craig, R.F.; Sim, B.S. Behavioral Science E Policy; Brookings Instition Press: Washington, DC, USA, 2017.

18. Allcott, H.; Mullainathan, S. Behavior and energy policy. Science 2010, 327, 1204. [CrossRef]

19. Andor, M.A.; Fels, K.M. Behavioral economics and energy conservation-a systematic review of non-price interventions and their causal effects. Ecol. Econ. 2018, 148, 178-210. [CrossRef]

20. Allcott, H. Social norms and energy conservation. J. Publ. Econ. 2011, 95, 1082-1095. [CrossRef]

21. Frederiks, E.R.; Stenner, K.; Hobman, E.V. Household energy use: Applying behavioural economics to understand consumer decision-making and behaviour. Renew. Sustain. Energy Rev. 2015, 41, 1385-1394. [CrossRef]

22. Hobman, E.V.; Frederiks, E.R.; Stenner, K.; Meikle, S. Uptake and usage of cost-reflective electricity pricing: Insights from psychology and behavioural economics. Renew. Sustain. Energy Rev. 2016, 57, 455-467. [CrossRef]

23. Elbaz, S.; Zaiţ, A. Efficient use of behavioral tools to reduce electricity demand of domestic consumers. Sci. Ann. Econ. Bus. 2016, 63, 89-107. [CrossRef]

24. International Energy Agency. Modernising Building Energy Codes; IEA: Paris, France, 2013.

25. Urge-Vorsatz, D.; Koeppel, S.; Mirasgedis, S. Appraisal of policy instruments for reducing buildings' co2 emissions. Build. Res. Inf. 2007, 35, 458-477. [CrossRef]

26. Rosenow, J.; Fawcett, T.; Eyre, N.; Oikonomou, V. Energy efficiency and the policy mix. In Building Research and Information; Taylor \& Francis: London, UK, 2016; pp. 1-13.

27. European Union. Directive 2012/27/eu of the European Parliament and of the Council; European Union, Ed.; European Union: Brussels, Belgium, 2012; Volume 2012/27/EU, p. 56.

28. United Nations Environment Program. Assessment of Instruments for Reducing Greenhouse Gas Emissions from Buildings; United Nations Organization: Nairobi, Kenya, 2007.

29. Hood, C. Summing up the Parts: Combining Policy Instruments for Least-Cost Climate Mitigation Strategies; IEA: Paris, France, 2011; p. 66.

30. Organisation for Economic Cooperation and Development. Greening Household Behaviour: The Role of Public Policy; OECD: Paris, France, 2011; p. 192.

31. Nadel, S.; Amann, J.; Hayes, S.; Bin, S.; Young, R.; Mackres, E.; Misuriello, H.; Watson, S. An Introduction to US Policies to Improve Building Efficiency; American Council for an Energy Efficient Economy: Washington, DC, USA, 2013.

32. Kahneman, D. Maps of bounded rationality: Psychology for behavioral economics. Am. Econ. Rev. 2003, 93, 1449. [CrossRef]

33. Ariely, D. Predictably Irrational: The Hidden Forces that Shape our Decisions; Harper: New York, NY, USA, 2008. 
34. Blasch, J.; Filippini, M.; Kumar, N. Boundedly rational consumers, energy and investment literacy, and the display of information on household appliances. Resour. Energy Econ. 2017, 56, 39-58. [CrossRef]

35. Organisation for Economic Cooperation and Development. Behavioural Insights and Public Policy; OECD: Paris, France, 2017.

36. Klotz, L. Using behavioural science to redesign the built environment. In Behavioral Science Weekly Roundup; Behavioural Science \& Policy Association: Durham, NC, USA, 2017.

37. Malhotra, N.K. Information load and consumer decision making. J. Consum. Res. 1982, 8, 419-430. [CrossRef]

38. Schwartz, B. The Paradox of Choice: Why More is Less/Barry Schwartz. 1st Ecco paperback edition, 1st Ecco paperback ed.; HarperCollins: New York, NY, USA, 2005.

39. Gowdy, J.M. Behavioral economics and climate change policy. J. Econ. Behav. Organiz. 2008, 68, 632-644. [CrossRef]

40. Lorch, R. Climate policies for buildings. Build. Res. Inf. 2017, 45, 475-477. [CrossRef]

41. Harrington, P.; Toller, V. Best Practice Policy and Regulation for Low Carbon Outcomes in the Built Environment; Cooperative Research Centre for Low Carbon Living: Sydney, Australia, 2017.

42. Klotz, L.; Mack, D.; Klapthor, B.; Tunstall, C.; Harrison, J. Unintended anchors: Building rating systems and energy performance goals for u.S. Buildings. Energy Policy 2010, 38, 3557-3566. [CrossRef]

43. Delgado, L.; Shealy, T. Opportunities for greater energy efficiency in government facilities by aligning decision structures with advances in behavioral science. Renew. Sustain. Energy Rev. 2018, 82, 3952-3961. [CrossRef]

44. McNamara, S.; Grubb, M. The Psychological Underpinnings of the Consumer Role in Energy Demand and Carbon Abatement; University of Cambridge: Cambridge, UK, 2011.

45. Baddeley, M. Energy, the Environment and Behaviour Change: A Survey of Insights from Behavioural Economics; University of South Australia: Adelaide, Australia, 2011.

46. Baddeley, M. Behavioral approaches to managing household energy consumption. In New Perspectives for Environmental Policies through Behavioral Economics; Springer: Berlin/Heidelberg, Germany, 2016; pp. 213-235.

47. Allcott, H.; Rogers, T. The short-run and long-run effects of behavioral interventions: Experimental evidence from energy conservation. Am. Econ. Rev. 2014, 104, 3003-3037. [CrossRef]

48. Klotz, L. Cognitive biases in energy decisions during the planning, design, and construction of commercial buildings in the united states: An analytical framework and research needs. Energy Effic. 2011, 4, 271-284. [CrossRef]

49. Yoeli, E.; Budescu, D.V.; Carrico, A.R.; Delmas, M.A.; DeShazo, J.; Ferraro, P.J.; Forster, H.A.; Kunreuther, H.; Larrick, R.P.; Lubell, M. Behavioral science tools to strengthen energy \& environmental policy. Behav. Sci. Policy 2017, 3, 68-79.

50. Shealy, T.; Klotz, L.; Weber Elke, U.; Johnson Eric, J.; Bell Ruth, G. Using framing effects to inform more sustainable infrastructure design decisions. J. Constr. Eng. Manag. 2016, 142, 04016037. [CrossRef]

51. Laustsen, J. Energy Efficiency Requirements in Building Codes, Energy Efficiency Policies for New Buildings; International Energy Agency: Paris, France, 2008.

52. Deason, J.; Hobbs, A. Codes to Cleaner Buildings: Effectiveness of us Building Energy Codes; Version 1; Climate Policy Initiative: San Francisco, CA, USA, 2011.

53. Koirala, B.S.; Bohara, A.K.; Li, H. Effects of energy-efficiency building codes in the energy savings and emissions of carbon dioxide. Environ. Econ. Policy Stud. 2013, 15, 271-290. [CrossRef]

54. Livingston, O.V.; Cole, P.C.; Elliott, D.B.; Bartlett, R. Building Energy Codes Program: National Benefits Assessment, 1992-2040; PNNL-22610; US Department of Energy: Richland, WA, USA, 2014.

55. CSIRO. Evaluation of the 5 Star Energy Efficiency Standard for Residential Buildings; CSIRO: Canberrra, Australia, 2013.

56. Moore, T.; Berry, S.; Ambrose, M. Aiming for mediocrity: The case of australian housing thermal performance. Energy Policy 2019, 132, 602-610. [CrossRef]

57. Pan, W.; Garmston, H. Building regulations in energy efficiency: Compliance in England and Wales. Energy Policy 2012, 45, 594-605. [CrossRef]

58. Meacham, B.J. Performance-Based Building Regulatory Systems: Principles and Experiences; IRCC: Ottawa, ON, Canada, 2010; p. 175.

59. Meacham, B.J. Sustainability and resiliency objectives in performance building regulations. Build. Res. Inf. 2016, 44, 474-489. [CrossRef] 
60. Gann, D.M.; Wang, Y.; Hawkins, R. Do regulations encourage innovation?-the case of energy efficiency in housing. Build. Res. Inf. 1998, 26, 280-296. [CrossRef]

61. Australian Building Codes Board. National Construction Code Series; ABCB: Canberra, Australia. Available online: http://www.abcb.gov.au (accessed on 30 August 2017).

62. AECOM. Understanding How the Building Industry Responds to Energy Efficiency Standards; Department of Climate Change \& Energy Efficiency: Canberra, Australia, 2012.

63. Australian Building Codes Board. ABCB Annual Business Plan 2014-2015; ABCB: Canberra, Australia. Available online: http://www.abcb.gov.au (accessed on 30 August 2017).

64. Ryghaug, M.; Sørensen, K.H. How energy efficiency fails in the building industry. Energy Policy 2009, 37, 984-991. [CrossRef]

65. Sustainable Built Environments. Benchmarking Study of Residential Building Performance; Building Commission of Victoria: Melbourne, Australia, 2010.

66. Arcipowska, A.; Anagnostopoulos, F.; Mariottini, F.; Kunkel, S. Energy Performance Certificates Across the EU; Buildings Performance Institute Europe: Brussels, Belgium, 2014.

67. Pitt \& Sherry, S.U. National Energy Efficient Building Project Report; Department of State Development: Adelaide, Australia, 2014.

68. Nicholas, S. Sir. Stern Review on the Economics of Climate Change; HM Treasury: London, UK, 2006.

69. Pachauri, R.K.; Meyer, L.A. Climate change 2014: Synthesis report. Contribution of working groups $i$, ii and iii to the fifth assessment report of the intergovernmental panel on climate change; International Panel on Climate Change: Geneva, Switzerland, 2014.

70. Amecke, $\mathrm{H}$. The impact of energy performance certificates: A survey of german home owners. Energy Policy 2012, 46, 4-14. [CrossRef]

71. Backhaus, J.; Tigchelaar, C.; de Best-Waldhober, M. Key Findings \& Policy Recommendations to Improve Effectiveness of Energy Performance Certificates $\mathcal{E}$ the Energy Performance of Buildings Directive; Energy research Centre of the Netherlands (ECN): Schagen, The Netherlands, 2011; p. 47.

72. International Energy Agency. Energy Performance Certification of Buildings; IEA: Paris, France, 2010.

73. European Union. Directive 2010/31/eu of the european parliament and of the council of 19 may 2010 on the energy performance of buildings; European Union: Brussels, Belgium, 2010.

74. European Union. Implementing the energy performance of buildings directive. Available online: https: //www.epbd-ca.eu (accessed on 3 October 2017).

75. Department of the Environment, Water, Heritage and the Arts. Energy Use in the Australian Residential Sector: 1986-2020; Commonwealth of Australia: Canberra, Australia, 2008.

76. Olaussen, J.O.; Oust, A.; Solstad, J.T. Energy Performance Certificates-Informing the informed or indifferent. Energy Policy 2017, 111, 246-254. [CrossRef]

77. Murphy, L. The influence of the energy performance certificate: The dutch case. Energy Policy 2014, 67, 664-672. [CrossRef]

78. Institute for market transformation. Transformation. Available online: https://www.imt.org/about/ (accessed on 27 April 2018).

79. Hårsman, B.; Daghbashyan, Z.; Chaudhary, P. On the quality and impact of residential energy performance certificates. Energy Build. 2016, 133, 711-723. [CrossRef]

80. Koklic, M.K.; Vida, I. Consumer strategic decision making and choice process: Prefabricated house purchase. Int. J. Consum. Stud. 2011, 35, 634-643. [CrossRef]

81. Climate Works Australia. Building Codes Energy Performance Trajectory Project; Australian Sustainable Built Environment Council: Sydney, Australia, 2018; p. 56.

82. Office of Environment and Heritage. A Draft Plan to Save NSW Energy and Money; Government of the State of New South Wales: Sydney, Australia, 2016.

83. International Energy Agency. Transition to Sustainable Buildings; OECD/IEA: Paris, France, 2013.

84. Thaler, R.H.; Sunstein, C.R. Nudge: Improving Decisions about Health, Wealth and Happiness; Penguin: New York, NY, USA, 2009.

85. Mark, L. Passivhaus: The dos and don'ts. The Architects' Journal, 16 October 2013. 
86. Commonwealth of Australia. Your Home. Available online: http://www.yourhome.gov.au (accessed on 3 August 2018).

87. Kruzner, K.; Cox, K.; Machmer, B.; Klotz, L. Trends in observable passive solar design strategies for existing homes in the us. Energy Policy 2013, 55, 82-94. [CrossRef] 